\title{
Raloxifene in the Treatment of Osteoporosis in Postmenopausal Women with End-Stage Renal Disease: A Systematic Review and Meta-Analysis
}

\author{
Authors \\ Affiliations \\ 1 Department of Geriatrics, The Second Affiliated Hospital \\ of Zhejiang University School of Medicine, Hangzhou, \\ China \\ 2 Jiangsu Key Laboratory of Pediatrics, Nanjing Medical \\ University, Nanjing, China \\ 3 Nanjing Key Laboratory of Pediatrics, Children's Hospital \\ of Nanjing Medical University, Nanjing, China
}

Hao-Yang $\mathrm{Ma}^{1}{ }^{*}$, Shuang Chen ${ }^{2,3}{ }^{*}$, Ling-Ling Lu2, 3, Wei Gong2, 3 , Ai-Hua Zhang2, 3

Key words

osteoporosis, osteopenia, postmenopause, end-stage renal disease, raloxifene

received 06.04.2020

accepted after revision $\quad 16.09 .2021$

Bibliography

Horm Metab Res 2021; 53: 730-737

DOI 10.1055/a-1655-4362

ISSN 0018-5043

(c) 2021. Thieme. All rights reserved.

Georg Thieme Verlag, Rüdigerstraße 14,

70469 Stuttgart, Germany

Correspondence

Ai-Hua Zhang

Department of Nephrology

Children's Hospital of Nanjing Medical University

72 Guangzhou Road

210008 Nanjing

China

Tel.: + 8657187784583

zhaihua@njmu.edu.cn

\section{ABSTRACT}

As a selective estrogen receptor modulator (SERM), raloxifene is used in healthy postmenopausal women to prevent bone loss and reduce fractures. However, the benefit of raloxifene is uncertain in the treatment of osteoporosis among patients with end-stage renal disease (ESRD) or those who require maintenance dialysis. We assessed the safety and efficacy of raloxifene in this particular population. Studies were selected from PubMed, Springer, CNKI (Chinese National Knowledge Infrastructure) and Wanfang Database. Randomized controlled trials (RCTs) and prospective studies with control/placebo groups were included. Five studies were included with a total of 244 participants (121 patients in the raloxifene group and 123 patients in the placebo/control group). The median duration of treatment was 12 months. The incidence rate of side effects of raloxifene was $0 / 121(0 \%)$. There was a significant improvement of lumbar spine bone mineral density (BMD) levels in the raloxifene group compared with the placebo group (MD: 33.88 , $95 \% \mathrm{Cl}: 10.93,56.84, p=0.004)$. There was no significant difference concerning the improvement of femoral neck BMD (MD: 8.42, 95\% Cl: $-10.21,27.04, \mathrm{p}=0.38$ ), intact parathyroid hormone (iPTH) (MD: $-12.62,95 \% \mathrm{Cl}:-35.36,10.13, \mathrm{p}=0.28$ ), calcium (MD: $-0.08,95 \% \mathrm{Cl}:-0.61,0.44, \mathrm{p}=0.76$ ), phosphorus (MD: $0.18,95 \% \mathrm{Cl}:-0.12,0.48, \mathrm{p}=0.23$ ) or bone alkaline phosphatase (BAP) (MD: $-4.33,95 \% \mathrm{Cl}:-14.44,5.79, \mathrm{p}=0.40$ ). Raloxifene seems to be effective in improving the lumbar spine BMD in postmenopausal women with ESRD. More large RCTs are necessary to evaluate the long-term safety of raloxifene in uremic patients.

\section{Introduction}

Osteoporosis is a systemic disorder characterized by reduced bone mineral density (BMD) and altered skeletal microarchitecture, leading to increased bone fragility with subsequent increased risk for fracture. According to the new diagnostic criteria for osteoporosis

These authors contributed equally to this work recommended by the National Bone Health Alliance (NBHA), $30-50 \%$ of women over 50 years old have osteoporosis worldwide $[1,2]$. These women have a 15-20\% lifetime risk of hip fracture and a $50 \%$ risk of any osteoporotic fracture [3]. Preclinical studies have suggested that the deficiency of estrogen could accelerate the progress of postmenopausal osteoporosis through multiple mechanisms [4-6]. For instance, hypoxia inducible factor 1 alpha (HIF1 $\alpha$ ), an essential factor for osteoclast activation, could be induced and 
accumulated under menopausal condition. On the contrary, genetic inactivation or pharmacological inhibition of HIF1 $\alpha$ in osteoclasts alleviated postmenopausal bone loss [4]. Moreover, estrogen deficiency was associated with an enhanced inflammatory milieu that was correlated with bone inflammation and osteoporosis $[5,7]$. In vitro experiments further revealed that bone cell mineralization and apoptosis were altered upon estrogen withdrawal $[6,8]$.

Patients with chronic kidney disease (CKD) often develop CKD-mineral bone disorders (CKD-MBD) due to secondary hyperparathyroidism. These patients might have high-turnover bone diseases such as osteitis fibrosa, low-turnover bone diseases such as osteomalacia or adynamic bone disease, and mixed forms $[9,10]$. Both high and low bone turnover in CKD-MBD patients are associated with increased risk of fracture and mortality [11]. Epidemiologic studies suggested that patients with CKD had higher risk of developing fractures $[12,13]$, and that this risk was increased in those with end-stage renal disease (ESRD) who required maintenance dialysis $[14,15]$. The risk of hip and/or vertebral fractures was further increased in postmenopausal women with the deterioration of kidney function $[16,17]$. The mainstays of therapy for CKD-MBD include dietary phosphorus restriction, phosphate binders, dialysis, calcimimetics with calcitriol or vitamin D analogs, and parathyroidectomy, which aim to restore the balance between calcium, parathyroid hormone (PTH), phosphorus and vitamin D $[18,19]$.

Osteoporosis intertwined with CKD-related bone disorders makes the clinical picture more complicated in postmenopausal uremic patients. Although antiresorptive medications including bisphosphonates and selective estrogen receptor modulators (SERMs) are widely used and well-tolerated in the general population, they are actually labeled with warnings for use or contraindicated in patients with severe CKD [20]. Besides, some of the agents may be suitable only in patients without low turnover or adynamic bone disease [21]. Consequently, the Kidney Disease Improving Global Outcomes (KDIGO) 2017 CKD-MBD Update Work Group recommended that clinicians should be aware of the specific side effects of conventional antiresorptive therapies for osteoporosis as they might exacerbate low bone turnover in patients with ESRD [22]. Therefore, SERMs such as raloxifene and bazedoxifene should be administered with extreme caution in postmenopausal uremic patients without definite bone biopsy results.

Although the role of SERMs in treating osteoporosis have been studied in postmenopausal women [23, 24], randomized controlled trials regarding the safety and efficacy of SERMs in the management of postmenopausal ESRD patients are scarce. A recent posthoc analysis suggested that raloxifene therapy might be safe and renoprotective in postmenopausal women with osteoporosis and mild to moderate CKD (to CKD stage 3) [25]. However, an in-depth analysis about the benefit of raloxifene, in the treatment of osteoporosis among ESRD patients or those who require maintenance dialysis, is lacking.

The aim of the present review was to summarize the published literature about the safety and efficacy of raloxifene in postmenopausal osteoporotic patients with ESRD.

\section{Materials and Methods}

This meta-analysis is reported in line with the Assessing the Methodological Quality of Systematic Reviews (AMSTAR) and the Preferred Reporting Items for Systematic Reviews and Meta-Analyses Statement (PRISMA) recommendations [26].

\section{Search strategy}

PubMed, Springer, CNKI (Chinese National Knowledge Infrastructure) and Wanfang Database were searched with one or a combination of the following terms: raloxifene, selective estrogen receptor modulator, osteopenia, osteoporosis, postmenopausal, chronic kidney disease, end-stage renal disease, uremia, peritoneal dialysis, and hemodialysis. In addition, the relevant references and cited papers were searched manually to identify additional studies meeting the inclusion criteria.

\section{Inclusion and exclusion criteria}

The inclusion criteria were: (1) original research papers written in English; (2) the study participants were human; (3) randomized controlled trials (RCTs) or prospective studies with control or placebo groups; (4) studies of perimenopausal/postmenopausal patients diagnosed with osteopenia/osteoporosis[27, 28]; (5) studies of patients with CKD stage 5 with or without maintenance dialysis; and (6) studies with a follow-up period of at least 6 months.

The exclusion criteria were: (1) retrospective studies, case reports, reviews, in vitro studies, and animal studies; (2) studies consisting of patients with CKD not reaching CKD stage 5; (3) studies in which patients were also treated with any other drugs intended for the treatment of osteopenia/osteoporosis except for vitamin D and calcium salts; and (4) studies with a lack of relevant outcome data.

\section{Outcomes and outcome measurements}

(1) Safety profile: Possible side effects of raloxifene listed in the articles included breast cancer, cervical carcinoma, thrombosis, thromboembolism, cerebral and myocardial infarction. All the included studies investigated these potential adverse effects.

(2) Bone mineral density (BMD): Two studies provided relevant data on lumbar spine or femoral neck BMD by employing dual energy X-ray absorptiometry (DEXA) [29, 30]. Data regarding the speed of the sound (SOS) in the calcaneus region, which was thought to be positively correlated with the lumbar BMD in the general population and used to estimate the bone density of participants, could be obtained from one study [27].

(3) Bone metabolism markers: One study reported the serum level of N-terminal cross-linking telopeptide of type I collagen (NTx) and another one specified serum alkaline phosphatase (ALP) in the follow-up [27, 30]. Three studies provided exact data on calcium, PTH and phosphorus [27, 30, 31]. Information regarding bone alkaline phosphatase (BAP) could be obtained from two studies [27, 31].

\section{Data extraction and the assessment of risk of bias}

All data were extracted independently by two reviewers using a paper data extraction form. The accuracy of the extracted data was further confirmed by a third author. The extracted information in- 
cluded: author and year of publication, study design, participants, interventions and follow-ups, treatment outcomes and key conclusions. For continuous data, we extracted the mean value and converted standard error of the mean (SEM) to standard deviation (SD). Two raters independently assessed the methodological quality of the included studies in accordance with the Cochrane Collaboration guidelines [32]. We assessed the risk of bias from the following six aspects: sequence generation, allocation concealment, blinding of participants and personnel, blinding of outcome assessment, incomplete outcome data and selective outcome reporting.

\section{Statistical analysis}

We performed the analysis using R program (version 3.4.4) and Review Manager Version 5.2. We used mean differences (MD) to estimate continuous variables with $95 \%$ confidence interval $(\mathrm{Cl})$. A p-value of $<0.05$ was considered statistically significant. Heterogeneity among the studies was assessed with the inconsistency fac$\operatorname{tor}\left(I^{2}\right) . I^{2}>50 \%$ or $p<0.10$ was considered to indicate significant heterogeneity. Whenever $I^{2}$ was $<50 \%$, the fixed-effects model results were used; otherwise, the random-effects model results were used.

\section{Results}

\section{Study selection}

A PRISMA flowchart of the selection process is shown in > Fig. 1. After discarding the duplicate studies and screening, 10 studies were selected for full-text examination. One study was excluded because there was no placebo/control group [33]. One study was excluded because patients had normal baseline kidney functions [34]. One retrospective study was also excluded [35]. Two studies

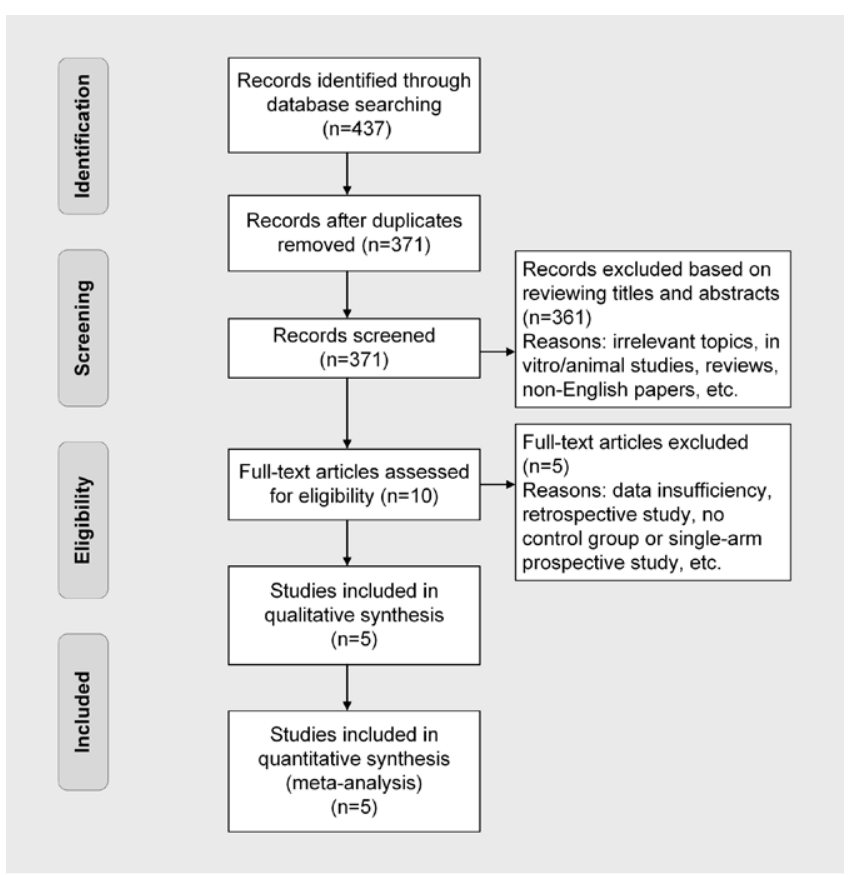

Fig. 1 Flowchart of paper selection. were excluded because of insufficient data [36, 37]. Five studies fulfilled the inclusion criteria and were ultimately included in this analysis [27, 29-31, 38].

\section{Characteristics and risk of bias of the included studies}

In total, 121 patients were included in the raloxifene group, and 123 patients were enrolled in the placebo/control group. The median duration of treatment was 12 months. The follow-up period ranged from 8-12 months. The PICOS approach was used to summarize the characteristics of the included studies ( $\triangleright$ Table 1). An assessment of the risk of bias using Cochrane Collaboration's tool is shown in $>$ Fig. 2 a, $\mathbf{b}$.

\section{Meta-analysis results}

\section{Safety of raloxifene in postmenopausal osteoporotic patients with ESRD}

All studies reported the incidence rate of side effects of raloxifene: $0 / 121(0 \%)$ in the raloxifene group. Potential adverse effects of raloxifene include deep vein thrombosis (DVT), venous thromboembolism (VTE), stroke, and ischemic cardiovascular events [39]. One patient in the placebo group had lumbar spine fracture by the end of follow-up.

\section{Improvement of femur BMD}

Data about femoral neck BMD $\left(\mathrm{mg} / \mathrm{cm}^{2}\right)$ at baseline and the end of follow-up were reported in two articles. There was no significant heterogeneity among the studies ( $p=0.70,1^{2}=0 \%$ ), so the fixed-effects model was used for the meta-analysis. There was no significant difference between the groups concerning the improvement of femoral neck BMD (MD: -0.02, 95\% Cl: -0.04, 0.00, p=0.38) (> Fig. 3a).

Improvement of lumbar spine BMD

Data about lumbar spine BMD $\left(\mathrm{mg} / \mathrm{cm}^{2}\right)$ at baseline and the end of follow-up were reported in two articles. There was no significant heterogeneity among the studies ( $p=0.98,12=0 \%)$, so the fixed-effects model was applied in the meta-analysis. There was a significant improvement of lumbar spine BMD levels in the raloxifene group (MD: 33.88, $95 \% \mathrm{Cl}: 10.93,56.84, \mathrm{p}=0.004)$ ( Fig. 3b).

\section{iPTH level}

Data about iPTH levels $(\mathrm{pg} / \mathrm{ml})$ were reported in three articles. There was no significant heterogeneity among the studies $(p=0.53$, $\mathrm{I}^{2}=0 \%$ ), so the fixed-effects model was used for the meta-analysis. There was no significant difference between the groups concerning iPTH levels (MD: -12.62 , 95 \% Cl: $-35.36,10.13, p=0.28$ ) (> Fig. 4a).

\section{Calcium level}

Data about calcium levels $(\mathrm{mg} / \mathrm{dl})$ were reported in three articles. There was a significant heterogeneity among the studies $\left(p<0.01, \mathrm{I}^{2}=84 \%\right)$, so the random-effects model was used for the meta-analysis. There was no significant difference between the groups concerning calcium levels (MD: $-0.08,95 \% \mathrm{Cl}:-0.61,0.44, \mathrm{p}=0.76$ ) ( Fig. 4b).

\section{Phosphorus level}

Data about phosphorus levels $(\mathrm{mg} / \mathrm{dl}$ ) were reported in three articles. There was no significant heterogeneity among the studies 
- Table 1 Summary of characteristics of the included studies.

\begin{tabular}{|c|c|c|c|c|c|}
\hline $\begin{array}{l}\text { Author, } \\
\text { year [Ref] }\end{array}$ & Study design & Participants & Interventions/follow-up & Outcomes & Key findings \\
\hline $\begin{array}{l}\text { Hernandez } \\
\text { et al. } 2003 \\
\text { [29] }\end{array}$ & $\begin{array}{l}\text { Prospective, blind, } \\
\text { placebo-controlled, } \\
\text { and randomized } \\
\text { study. } \\
\text { Withdrawal: } 0 \% \text {. } \\
\text { Two centers in } \\
\text { Venezuela. }\end{array}$ & $\begin{array}{l}50 \text { postmenopausal patients } \\
\text { on HD. Age: } 62.5 \pm 8.58 \\
\text { years. Diagnosed with } \\
\text { severe osteopenia or } \\
\text { osteoporosis (T score } \\
\text { below-2.0SD). }\end{array}$ & $\begin{array}{l}\text { Group } R(n=25) \text { : } \\
\text { raloxifene, } 60 \text { mg/d. } \\
\text { Group P }(n=25) \text { : placebo. } \\
\text { Follow-up: } 12 \text { months. }\end{array}$ & $\begin{array}{l}\text { L2-L4 lumbar spine } \\
\text { BMD and femoral } \\
\text { neck BMD. } \\
\text { Serum lipid panel: TC, } \\
\text { LDL-cholesterol, } \\
\text { HDL-cholesterol, } \\
\text { triglycerides. }\end{array}$ & $\begin{array}{l}\text { Drug side effects }{ }^{*}: 0 \% \text {. } \\
\text { An improvement in lumbar } \\
\text { spine BMD and a slight } \\
\text { increase of HDL-cholesterol } \\
\text { in patients taking } \\
\text { raloxifene. } \\
\text { Decreased serum levels of } \\
\text { LDL-cholesterol and } \\
\text { pyridinoline crosslinks in } \\
\text { raloxifene group. }\end{array}$ \\
\hline $\begin{array}{l}\text { Saito et al. } \\
2011 \text { [31] }\end{array}$ & $\begin{array}{l}\text { Randomized and } \\
\text { controlled } \\
\text { interventional study. } \\
\text { Withdrawal: } 0 \% \text {. } \\
\text { Single center in } \\
\text { Japan. }\end{array}$ & $\begin{array}{l}47 \text { patients on HD ( } 6 \\
\text { perimenopausal and } 41 \\
\text { postmenopausal). Age: } \\
63.8 \pm 13.3 \text { years. Diagnosed } \\
\text { with osteoporosis (an } \\
\text { increase of NTx and a } \\
\text { decrease of calcaneus SOS). }\end{array}$ & $\begin{array}{l}\text { Group } R(n=21) \text { : } \\
\text { raloxifene, } 60 \mathrm{mg} / \mathrm{d} \text {, } \\
\text { postprandial. } \\
\text { Group P ( } n=26) \text {. } \\
\text { Follow-up: } 12 \text { months. }\end{array}$ & $\begin{array}{l}\text { Lumbar BMD } \\
\text { reflected by SOS in } \\
\text { the calcaneus region. } \\
\text { Serum NTx, BAP, and } \\
\text { iPTH, etc. }\end{array}$ & $\begin{array}{l}\text { Drug side effects: } 0 \% \text {. } \\
\text { Treatment with raloxifene } \\
\text { led to a significant decline } \\
\text { of NTx and an improve- } \\
\text { ment of BMD reflected by } \\
\text { the increased calcaneus } \\
\text { SOS. }\end{array}$ \\
\hline $\begin{array}{l}\text { Tanaka, } \\
\text { et al. } 2011 \\
\text { [38] }\end{array}$ & $\begin{array}{l}\text { Prospective } \\
\text { controlled study. } \\
\text { Withdrawal: } 0 \% \text {. } \\
\text { Multiple centers in } \\
\text { Japan. }\end{array}$ & $\begin{array}{l}27 \text { postmenopausal patients } \\
\text { on HD. Age: } 63.23 \pm 5.09 \\
\text { years. Patients receiving } \\
\text { raloxifene were diagnosed } \\
\text { with severe osteoporosis. } \\
\text { Patients in the control group } \\
\text { had similar baseline mean } \\
\text { lumbar spine BMD levels. }\end{array}$ & $\begin{array}{l}\text { Group } R(n=17) \text { : } \\
\text { raloxifene, } 60 \mathrm{mg} / \mathrm{d} \text {. } \\
\text { Group } \mathrm{P}(\mathrm{n}=10) \text {. } \\
\text { Vitamin } \mathrm{D} \text { and calcium } \\
\text { salts dosages were not } \\
\text { changed throughout the } \\
\text { study period. Follow-up: } \\
12 \text { months. }\end{array}$ & $\begin{array}{l}\text { BMD of the radius } \\
\text { and lumbar spine } \\
\text { determined by DEXA. } \\
\text { Serum bone } \\
\text { metabolism markers } \\
\text { such as calcium, } \\
\text { phosphorus, iPTH, } \\
\text { ALP, BAP, NTx, etc. }\end{array}$ & $\begin{array}{l}\text { Drug side effects: } 0 \% \text {. } \\
\text { Raloxifene treatment } \\
\text { improved lumbar spine } \\
\text { BMD. It also reduced serum } \\
\text { calcium and increased } \\
\text { serum iPTH. Vitamin D and } \\
\text { calcium salts should be } \\
\text { added to the regimen. }\end{array}$ \\
\hline $\begin{array}{l}\text { Saito. et al. } \\
2012 \text { [27] }\end{array}$ & $\begin{array}{l}\text { Prospective } \\
\text { controlled study. } \\
\text { Withdrawal: } 0 \% \text {. } \\
\text { Single center in } \\
\text { Japan. }\end{array}$ & $\begin{array}{l}60 \text { postmenopausal patients } \\
\text { on HD. Age: } 66.1 \pm 10.9 \\
\text { years. Diagnosed with } \\
\text { osteopenia or osteoporosis } \\
\text { according to the value of } \\
\text { calcaneus SOS. }\end{array}$ & $\begin{array}{l}\text { Group } R \text { ( } n=28 \text {, consisting } \\
\text { of } 14 \text { diabetics and } 14 \\
\text { non-diabetics): raloxifene, } \\
60 \mathrm{mg} / \mathrm{d} \text {, postprandial. } \\
\text { Group } P \text { ( } \mathrm{n}=32 \text {, consisting } \\
\text { of } 16 \text { diabetics and } 16 \\
\text { non-diabetics). Follow-up: } \\
12 \text { months. }\end{array}$ & $\begin{array}{l}\text { Lumbar BMD } \\
\text { reflected by SOS in } \\
\text { the calcaneus. Serum } \\
\text { calcium, phosphorus, } \\
\text { NTx, BAP, and iPTH, } \\
\text { etc. }\end{array}$ & $\begin{array}{l}\text { Drug side effects: } 0 \% \text {. } \\
\text { Raloxifene treatment } \\
\text { resulted in a significant } \\
\text { decrease in NTx and an } \\
\text { increase in SOS in both } \\
\text { non-diabetic and diabetic } \\
\text { postmenopausal patients } \\
\text { on HD. }\end{array}$ \\
\hline $\begin{array}{l}\text { Haghverdi et } \\
\text { al. } 2014 \text { [30] }\end{array}$ & $\begin{array}{l}\text { Block-randomized, } \\
\text { placebo-controlled } \\
\text { trial. Withdrawal: } \\
0 \% . \\
\text { Single center in Iran. }\end{array}$ & $\begin{array}{l}\text { A total number of } 60 \\
\text { postmenopausal patients } \\
\text { (HD, } n=51 \text {; CKD stage } 5 \\
\text { without dialysis, } n=9 \text { ). } \\
\text { Age: } 62.8 \pm 11.77 \text { years. } \\
\text { Diagnosed with severe } \\
\text { osteopenia or osteoporosis } \\
\text { (T score below-2.0SD). }\end{array}$ & $\begin{array}{l}\text { Group } R \text { ( } n=30 \text {, including } \\
4 \text { patients without } \\
\text { dialysis): raloxifene, } \\
60 \mathrm{mg} / \mathrm{d} \text {. Group } \mathrm{P}(\mathrm{n}=30 \text {, } \\
\text { including } 5 \text { patients } \\
\text { without dialysis): placebo. } \\
\text { Follow-up: } 8 \text { months. }\end{array}$ & $\begin{array}{l}\text { Lumbar spine and } \\
\text { femoral neck BMD } \\
\text { determined by DEXA. } \\
\text { Serum calcium, } \\
\text { phosphorus, ALP and } \\
\text { iPTH, etc. }\end{array}$ & $\begin{array}{l}\text { Drug side effects: } 0 \% \text {. } \\
\text { One patient had lumbar } \\
\text { spine fracture in the } \\
\text { placebo group. Raloxifene } \\
\text { proved to be effective in } \\
\text { improving BMD. It had no } \\
\text { effect on controlling } \\
\text { secondary hyperparathy- } \\
\text { roidism in these patients. }\end{array}$ \\
\hline
\end{tabular}

HD: Hemodialysis; BMD: Bone mineral density; TC: Total cholesterol; LDL: Low-density lipoprotein; HDL: High-density lipoprotein; NTx: N-terminal cross-linking telopeptide of type I collagen; SOS: Speed of sound; BAP: Bone alkaline phosphatase; iPTH: Intact parathyroid hormone; DEXA: Dual energy X-ray absorptiometry; ALP: Alkaline phosphatase. ${ }^{*}$ Possible side effects of raloxifene listed in the cited papers include breast cancer, cervical carcinoma, thrombosis, thromboembolism, cerebral and myocardial infarction.

( $p=0.87, \mathrm{I}^{2}=0 \%$ ), so the fixed-effects model was applied in the meta-analysis. There was no significant difference between the groups concerning phosphorus levels (MD: $0.18,95 \% \mathrm{Cl}:-0.12,0.48$, $\mathrm{p}=0.23)(\triangleright$ Fig. 4c).

\section{BAP leve}

Data about BAP levels $(\mathrm{mg} / \mathrm{dl})$ were reported in two articles. There was no significant heterogeneity among the studies $(p=0.82$, $\mathrm{I}^{2}=0 \%$ ), so the fixed-effects model was applied in the meta-analysis. There was no significant difference between the groups concerning BAP levels (MD: -4.33 , $95 \% \mathrm{Cl}:-14.44,5.79, \mathrm{p}=0.40)$ ( Fig. 4d). 


\section{Discussion}

The declining level of estrogen in menopausal women put them at risk for osteoporosis and subsequent fractures. Randomized controlled trials suggested that the therapeutic property of estrogen

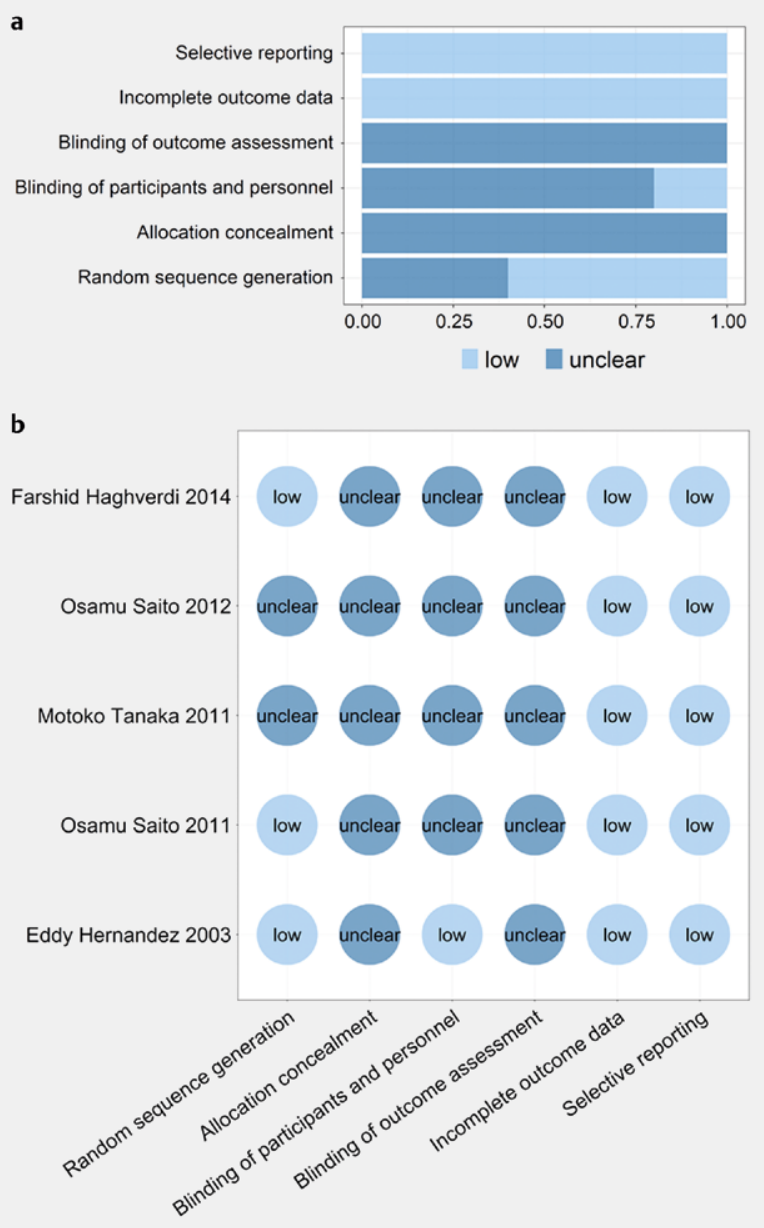

- Fig. 2 a: Risk of bias graph; b: Risk of bias summary. in postmenopausal osteoporosis might be associated with promoting the $\mathrm{Wnt} / \mathrm{\beta}$-catenin signaling pathway and reducing bone resorption [40,41]. Postmenopausal women treated with hormone therapy had lower serum levels of bone resorbing cytokines interleukin-1 $\beta$ (IL-1 $\beta$ ) and tumor necrosis factor $\alpha$ (TNF $\alpha)$ [42].

The safety and efficacy of SERMs in the treatment of osteoporosis have been well studied in postmenopausal women without severe renal impairments. Raloxifene treatment is associated with a 30 to $40 \%$ reduction in risk of one or more spine fractures and with extraskeletal benefits [43]. Nevertheless, it is associated with increased risk of venous thromboembolism, pulmonary embolism, and fatal stroke in postmenopausal women $[44,45]$.

Unfortunately, evidence is insufficient from clinical trials assessing the safety and efficacy of raloxifene in postmenopausal osteoporotic women with severe renal insufficiency or those who require maintenance dialysis. Because of the altered drug pharmacokinetics in patients with CKD, and because of the coexisting renal osteopathy caused by CKD itself, the safety profile of raloxifene should be carefully evaluated in those patients with ESRD. Moreover, patients with CKD are often complicated with other severe comorbidities such as vascular calcification, coronary artery disease, and stroke [46]. Coagulopathies such as hypercoagulability and thrombosis are commonly seen in uremic patients on maintenance hemodialysis [47]. These issues add more uncertainties and complexities on the use of raloxifene in patients with ESRD. The included studies in the present meta-analysis all showed that raloxifene could be well-tolerated in uremic patients without obvious side effects. However, we have to take into account the relatively short follow-up duration in these studies because some potential adverse effects might not occur in the short term [48].

The NBHA Work Group recommended that in postmenopausal women, osteoporosis be diagnosed based on any one of the three elements: traditional BMD based T-score, or qualified fractures, or a fracture risk assessment tool (FRAX) score [49]. The 2017 KDIGO guidelines recommended that BMD testing be assessed in patients with CKD-MBD and/or risk factors for osteoporosis [22]. Pooled analysis showed that there was a significant improvement of lum-

a

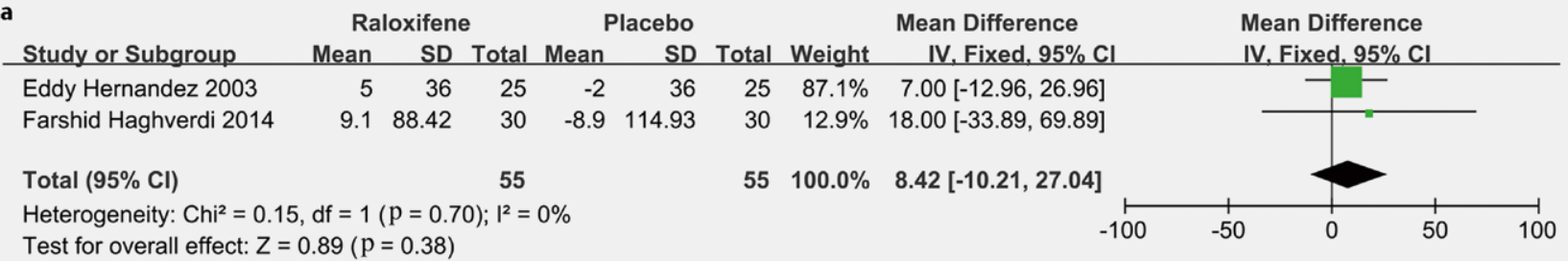

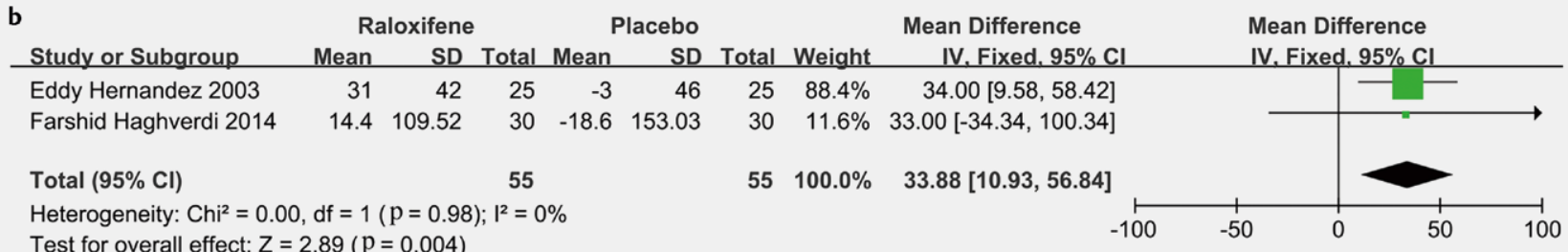

> Fig. 3 a: Forest plot analyzing the effect of raloxifene on improving femur BMD $\left(\mathrm{mg} / \mathrm{cm}^{2}\right)$; b: Forest plot analyzing the effect of raloxifene on improving lumbar spine BMD $\left(\mathrm{mg} / \mathrm{cm}^{2}\right)$. 


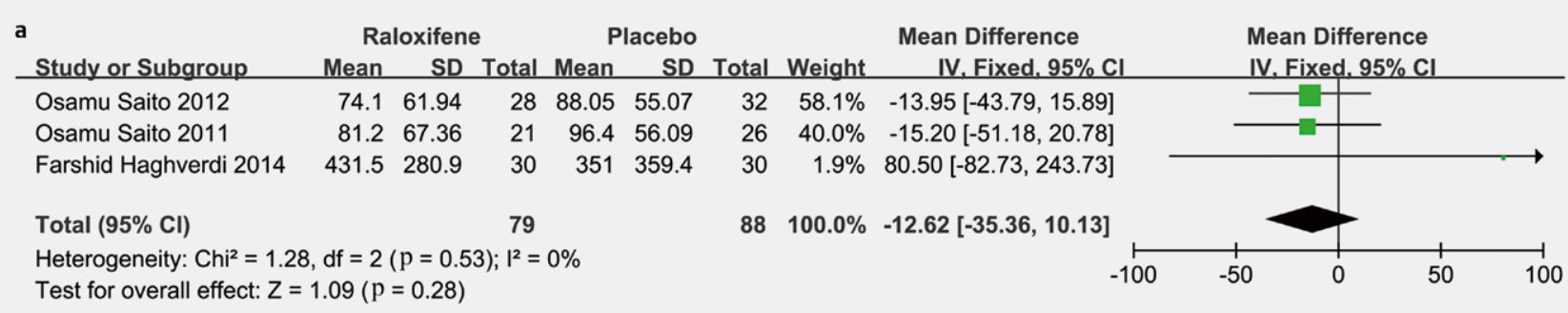

\begin{tabular}{|c|c|c|c|c|c|c|c|c|c|c|}
\hline \multirow[b]{2}{*}{ Study or Subgroup } & \multicolumn{3}{|c|}{ Raloxifene } & \multicolumn{2}{|c|}{ Placebo } & \multirow[b]{2}{*}{ Total } & \multirow[b]{2}{*}{ Weight } & \multirow{2}{*}{$\begin{array}{l}\text { Mean Difference } \\
\text { IV. Random, } 95 \% \mathrm{Cl}\end{array}$} & \multirow{2}{*}{\multicolumn{2}{|c|}{$\begin{array}{c}\text { Mean Difference } \\
\text { IV. Random, } 95 \% \mathrm{Cl}\end{array}$}} \\
\hline & Mean & SD & Total & Mean & SD & & & & & \\
\hline Osamu Saito 2012 & 8.98 & 0.64 & 28 & 8.7 & 0.56 & 32 & $35.6 \%$ & $0.28[-0.03,0.59]$ & & \\
\hline Osamu Saito 2011 & 9.3 & 0.962 & 21 & 9.32 & 0.867 & 26 & $28.8 \%$ & $-0.02[-0.55,0.51]$ & & \\
\hline Farshid Haghverdi 2014 & 8.9 & 0.5 & 30 & 9.4 & 0.7 & 30 & $35.6 \%$ & $-0.50[-0.81,-0.19]$ & & \\
\hline Total $(95 \% \mathrm{Cl})$ & & & 79 & & & 88 & $100.0 \%$ & $-0.08[-0.61,0.44]$ & & \\
\hline $\begin{array}{l}\text { Heterogeneity: } \mathrm{Tau}^{2}=0 \text {. } \\
\text { Test for overall effect: } Z\end{array}$ & $\begin{array}{l}\mathrm{Chi}^{2}= \\
0.31(\mathrm{p}\end{array}$ & $\begin{array}{r}12.48 \\
=0.76)\end{array}$ & $d f=2($ & $\mathrm{p}=0.0$ & D2); $\left.\right|^{2}=$ & $84 \%$ & & & -2 & 2 \\
\hline
\end{tabular}

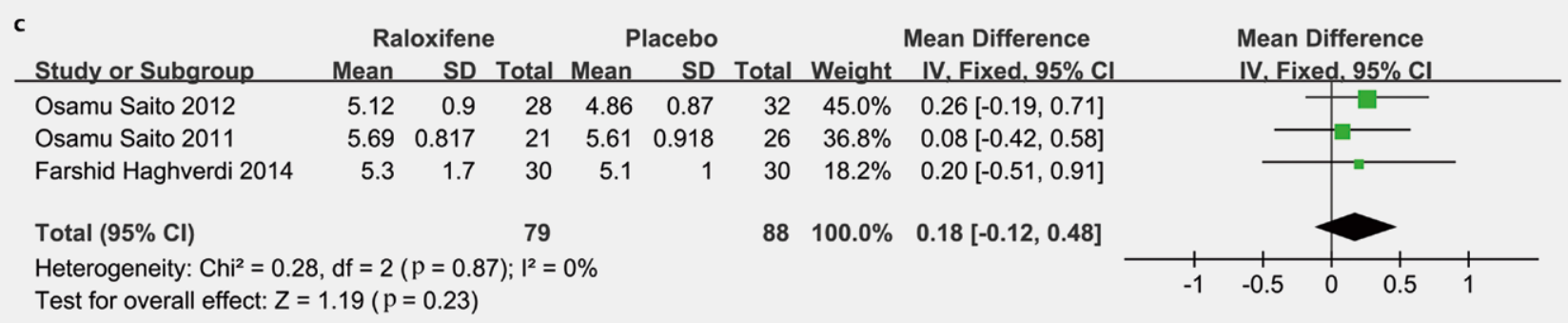

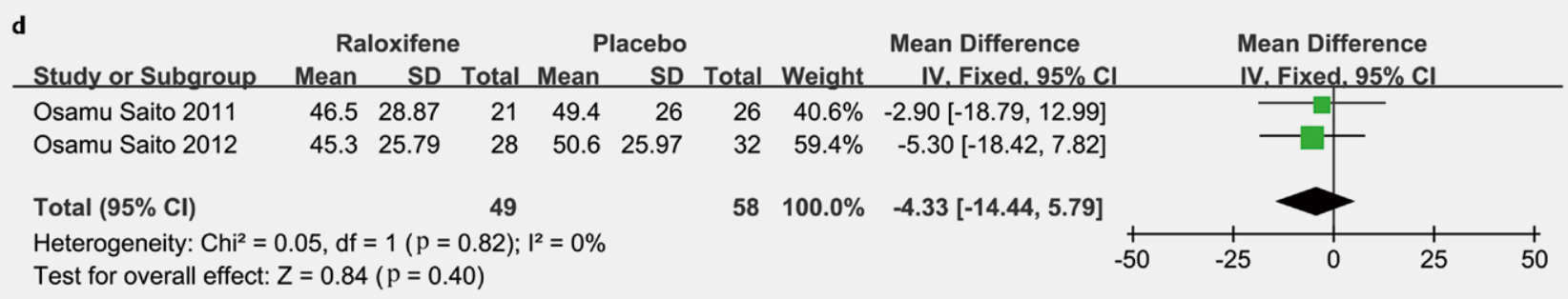

- Fig. 4 a: Forest plot of iPTH (pg/ml); b: Forest plot of calcium (mg/dl); c: Forest plot of phosphorus (mg/dl); d: Forest plot of BAP (mg/dl).

bar spine BMD levels in the raloxifene group compared with the placebo group. There was no significant difference in favor of the raloxifene group regarding the improvement of femoral neck BMD. This result was consistent with previous studies in which raloxifene reduced the risk of vertebral fractures, but not nonvertebral or hip fractures in osteoporotic women without severe renal impairments $[50,51]$.

Since antiresorptive agents such as raloxifene and other SERMs might exacerbate low bone turnover in patients with ESRD, the indications for a bone biopsy prior to initiating antiresorptives and other osteoporosis therapies should be addressed [22]. However, bone biopsy as the gold standard for assessment of bone turnover is quite limited by its invasiveness and cost [11]. The included studies in the present meta-analysis did not provide information about whether participants had actually undergone bone biopsy before taking raloxifene. The $2017 \mathrm{KDICO}$ guidelines recommended monitoring serum levels of calcium, phosphorus, PTH, and ALP beginning in CKD stage 3. In patients with advanced CKD stage, measurements of serum PTH or BAP could be used to evaluate the underlying bone turnover [10]. There has been controversy over the role of bone turnover markers in predicting certain clinical outcomes related to BMD [52-54]. Using multiple regression analysis, Osamu et al. found that changes of serum BAP and NTx were correlated with the change of SOS value over one year in female dialysis patients, which indicated that the sequential variation of bone turnover markers might be associated with the dynamic level of BMD [31]. To further investigate the effect of raloxifene on bone turnover markers, Osamu et al. reported that there was a significant increase in SOS and decrease in NTx in patients treated with raloxifene for one year [27,31]. However, Motoko et al. concluded that the level of NTx did not alter significantly in the raloxifene group as compared to the placebo group [38]. Studies by Farshid and Motoko et al. also revealed that no statistical difference regarding serum ALP existed between the two groups $[30,38]$. In this analysis, three studies provided data on serum levels of calcium, phosphorus and PTH; two studies reported the bone formation marker BAP. Pooled analysis showed no statistically 
significant difference between the raloxifene group and the placebo group regarding bone metabolism markers. Still, these data should be interpreted prudently because participants in these studies might have taken other drugs which had effects on bone turnover markers.

There are some limitations in our study. First, the number of included RCTs was limited and most of the studies had a small sample size, and this could lead to an overestimation of the efficacy of raloxifene in osteoporotic patients with ESRD. Second, the clinical outcomes were inadequate and outcome measurements were not uniform among the studies. Furthermore, differences in study protocols (e.g., the type of assay used for calcium measurement, the use of albumin-adjusted calcium, different normal ranges, etc.) might influence the interpretation of the treatment effect of raloxifene. Another limit is that the follow-up duration of the included studies was relatively short, which made it inappropriate to conclude that the use of raloxifene in patients with ESRD was safe and well-tolerated.

\section{Conclusion}

The present analysis reveals that raloxifene is more effective than placebo in improving the lumbar spine bone mineral density in postmenopausal women with end-stage renal disease. More large randomized controlled trials are necessary to evaluate the longterm safety of raloxifene in uremic patients.

\section{Conflict of Interest}

The authors declare that they have no conflict of interest.

\section{References}

[1] Wright NC, Saag KG, Dawson-Hughes B et al. The impact of the new National Bone Health Alliance (NBHA) diagnostic criteria on the prevalence of osteoporosis in the USA. Osteoporos Int 2017; 28: $1225-1232$

[2] Cipriani C, Pepe J, Bertoldo F et al. The epidemiology of osteoporosis in Italian postmenopausal women according to the National Bone Health Alliance (NBHA) diagnostic criteria: a multicenter cohort study. J Endocrinol Invest 2018; 41: 431-438

[3] Black DM, Rosen C]. Clinical practice. Postmenopausal osteoporosis. N Eng J Med 2016; 374: 254-262

[4] Miyauchi Y, Sato Y, Kobayashi T et al. HIF1a is required for osteoclast activation by estrogen deficiency in postmenopausal osteoporosis. Proc Natl Acad Sci USA 2013; 110: 16568-16573

[5] Raehtz S, Bierhalter $\mathrm{H}$, Schoenherr D et al. Estrogen deficiency exacerbates type 1 diabetes-induced bone TNF-a expression and osteoporosis in female mice. Endocrinology 2017; 158: 2086-2101

[6] Brennan M, Haugh MG, O'Brien F] et al. Estrogen withdrawal from osteoblasts and osteocytes causes increased mineralization and apoptosis. Horm Metab Res 2014; 46: 537-545

[7] Percegoni N, Ferreira AC, Rodrigues CF et al. Profile of serum IL-1 beta and IL-10 shortly after ovariectomy and estradiol replacement in rats. Horm Metab Res 2009; 41: 5054
[8] Brennan O, O'Brien FJ, McNamara LM. Estrogen plus estrogen receptor antagonists alter mineral production by osteoblasts in vitro. Horm Metab Res 2012; 44: 47-53

[9] Nitta K, Yajima A, Tsuchiya K. Management of osteoporosis in chronic kidney disease. Intern Med (Tokyo, Japan) 2017; 56: 3271-3276

[10] Bover ], Bailone L, López-Báez V et al. Osteoporosis, bone mineral density and CKD-MBD: treatment considerations. J Nephrol 2017; 30: 677-687

[11] Chiang $C$. The use of bone turnover markers in chronic kidney disease-mineral and bone disorders. Nephrology (Carlton, Vic) 2017; 22: $11-13$

[12] Dooley AC, Weiss NS, Kestenbaum B. Increased risk of hip fracture among men with CKD. Am J Kidney Dis 2008; 51: 38-44

[13] Nickolas TL, McMahon DJ, Shane E. Relationship between moderate to severe kidney disease and hip fracture in the United States. J Am Soc Nephrol 2006; 17: 3223-3232

[14] Jansz TT, Goto NA, van Ballegooijen AJ et al. The prevalence and incidence of vertebral fractures in end-stage renal disease and the role of parathyroid hormone. Osteoporos Int 2020; 31: 515-524

[15] Alem AM, Sherrard DJ, Gillen DL et al. Increased risk of hip fracture among patients with end-stage renal disease. Kidney Int 2000; 58 : 396-399

[16] Ensrud KE, Lui LY, Taylor BC et al. Renal function and risk of hip and vertebral fractures in older women. Arch Intern Med 2007; 167: 133-139

[17] LaCroix AZ, Lee JS, Wu L et al. Cystatin-C, renal function, and incidence of hip fracture in postmenopausal women. J Am Geriatr Soc 2008; 56 : 1434-1441

[18] Waziri B, Duarte R, Naicker S. Chronic kidney disease-mineral and bone disorder (CKD-MBD): Current perspectives. Int J Nephrol Renovasc Dis 2019; 12: 263-276

[19] Huimin C, Ying C, Changying $X$ et al. Effects of parathyroidectomy on plasma iPTH and (1-84) PTH levels in patients with stage 5 chronic kidney disease. Horm Metab Res 2018; 50: 761-767

[20] Miller PD, Jamal SA, Evenepoel P et al. Renal safety in patients treated with bisphosphonates for osteoporosis: a review. J Bone Mineral Res 2013; 28: 2049-2059

[21] Khairallah P, Nickolas TL. Management of osteoporosis in CKD. Clin ] Am Soc Nephrol 2018; 13: 962-969

[22] [Anonymous]. KDIGO 2017 Clinical practice guideline update for the diagnosis, evaluation, prevention, and treatment of chronic kidney disease-mineral and bone disorder (CKD-MBD). Kidney Int Suppl 2017; 7: 1-59

[23] Peng L, Luo Q, Lu H. Efficacy and safety of bazedoxifene in postmenopausal women with osteoporosis: a systematic review and meta-analysis. Medicine 2017; 96: e8659

[24] Eastell R, Rosen C], Black DM et al. Pharmacological management of osteoporosis in postmenopausal women: an endocrine society clinical practice guideline. J Clin Endocrinol Metab 2019; 104: 1595-1622

[25] Melamed ML, Blackwell T, Neugarten J et al. Raloxifene, a selective estrogen receptor modulator, is renoprotective: A post-hoc analysis. Kidney Int 2011; 79: 241-249

[26] Liberati A, Altman DG, Tetzlaff J et al. The PRISMA statement for reporting systematic reviews and meta-analyses of studies that evaluate health care interventions: Explanation and elaboration. J Clin Epidemiol 2009; 62: e1-e34

[27] Saito O, Saito T, Asakura S et al. Effects of raloxifene on bone metabolism in hemodialysis patients with type 2 diabetes. Int ] Endocrinol Metab 2012; 10: 464-469

[28] [Anonymous]. Assessment of fracture risk and its application to screening for postmenopausal osteoporosis. report of a WHO study group. WHO Tech Rep Ser 1994; 843: 1-129 
[29] Hernández E, Valera R, Alonzo E et al. Effects of raloxifene on bone metabolism and serum lipids in postmenopausal women on chronic hemodialysis. Kidney Int 2003; 63: 2269-2274

[30] Haghverdi F, Farbodara T, Mortaji S et al. Effect of raloxifene on parathyroid hormone in osteopenic and osteoporotic postmenopausal women with chronic kidney disease stage 5 . Iran J kidney Dis 2014; 8: 461-466

[31] Saito O, Saito T, Asakura S et al. The effects of raloxifene on bone turnover markers and bone mineral density in women on maintenance hemodialysis. Clin Exp Nephrol 2011; 15: 126-131

[32] Cumpston M, Li T, Page M] et al. Updated guidance for trusted systematic reviews: A new edition of the cochrane handbook for systematic reviews of interventions. Cochrane Database Syst Rev 2019; 10: Ed000142

[33] Nagatoya K, Nishimoto K, Shibahara $\mathrm{N}$ et al. Effects of raloxifene on bone metabolism in postmenopausal women on chronic hemodialysis. Clin Exp Nephrol 2015; 19: 939-946

[34] Hadjadj S, Gourdy P, Zaoui P et al. Effect of raloxifene - a selective oestrogen receptor modulator - on kidney function in post-menopausal women with type 2 diabetes: Results from a randomized, placebo-controlled pilot trial. Diabet Med 2007; 24: 906-910

[35] Ishani A, Blackwell T, Jamal SA et al. The effect of raloxifene treatment in postmenopausal women with CKD. J Am Soc Nephrol 2008; 19: $1430-1438$

[36] Adami S, Palacios S, Rizzoli R et al. The efficacy and safety of bazedoxifene in postmenopausal women by baseline kidney function status. Climacteric 2014; 17: 273-284

[37] Ozbasar D, Toros U, Ozkaya O et al. Raloxifene decreases serum malondialdehyde and nitric oxide levels in postmenopausal women with end-stage renal disease under chronic hemodialysis therapy. J Obstetr Gynaecol Res 2010; 36: 133-137

[38] Tanaka M, Itoh K, Matsushita K et al. Effects of raloxifene on bone mineral metabolism in postmenopausal Japanese women on hemodialysis. Therap Apheres Dialysis 2011; 15: 62-66

[39] Ellis AJ, Hendrick VM, Williams R et al. Selective estrogen receptor modulators in clinical practice: a safety overview. Expert Opin Drug Safety 2015; 14: 1799-1800

[40] Honisett SY, Tangalakis K, Wark J et al. The effects of hormonal therapy and exercise on bone turnover in postmenopausal women: $A$ randomised double-blind pilot study. Prilozi (Makedonska akademija na naukite i umetnostite Oddelenie za medicinski nauki) 2016; 37 : $23-32$
[41] Fujita K, Roforth MM, Demaray S et al. Effects of estrogen on bone mRNA levels of sclerostin and other genes relevant to bone metabolism in postmenopausal women. J Clin Endocrinol Metab 2014; 99 : E81-E88

[42] Uemura H, Kamada M, Maegawa M et al. Effect of hormone replacement therapy on the production of bone-resorbing cytokines by peripheral blood cells in postmenopausal women. Horm Metab Res 2005; 37: 226-230

[43] Seeman E. Raloxifene. ] Bone Mineral Metab 2001; 19: 65-75

[44] Mosca L, Grady D, Barrett-Connor E et al. Effect of raloxifene on stroke and venous thromboembolism according to subgroups in postmenopausal women at increased risk of coronary heart disease. Stroke 2009; 40: 147-155

[45] Khorsand I, Kashef R, Ghazanfarpour M et al. The beneficial and adverse effects of raloxifene in menopausal women: a mini review. J Menopaus Med 2018; 24: 183-187

[46] Hruska KA, Choi ET, Memon I et al. Cardiovascular risk in chronic kidney disease (CKD): the CKD-mineral bone disorder (CKD-MBD). Pediatr Nephrol (Berlin, Germany) 2010; 25: 769-778

[47] Molino D, De Lucia D, Gaspare De Santo N. Coagulation disorders in uremia. Sem Nephrol 2006; 26: 46-51

[48] Cuzick J. Long-term follow-up in cancer prevention trials (It ain't over 'til it's over). Cancer Prevent Res (Philadelphia, Pa) 2010; 3: 689-691

[49] Siris ES, Adler R, Bilezikian J et al. The clinical diagnosis of osteoporosis: a position statement from the national bone health alliance working group. Osteoporos Int 2014; 25: 1439-1443

[50] Ensrud KE, Stock JL, Barrett-Connor E et al. Effects of raloxifene on fracture risk in postmenopausal women: the Raloxifene Use for the Heart Trial. J Bone Mineral Res 2008; 23: 112-120

[51] Seeman E, Crans GG, Diez-Perez A et al. Anti-vertebral fracture efficacy of raloxifene: A meta-analysis. Osteoporos Int 2006; 17: 313-316

[52] Bonnick SL, Shulman L. Monitoring osteoporosis therapy: bone minera density, bone turnover markers, or both? Am J Med 2006; 119: S25-S31

[53] Jørgensen HS, Winther S, Bøttcher $\mathrm{M}$ et al. Bone turnover markers are associated with bone density, but not with fracture in end stage kidney disease: a cross-sectional study. BMC Nephrol 2017; 18: 284

[54] Kaji H, Nomura R, Yamauchi M et al. The usefulness of bone metabolic indices for the prediction of changes in bone mineral density after parathyroidectomy in patients with primary hyperparathyroidism. Horm Metab Res 2006; 38: 411-416 